\title{
Developing Children's Communication and Social Awareness Skills in Volcano Disaster Areas through Physical Education and Sports Programs
}

\author{
Soni Nopembri'1,2, Ahmad Rithaudin'1, Saryono', Yoshio Sugiyama3 \\ ${ }^{1}$ Faculty of Sports Sciences, Yogyakarta State University, Yogyakarta, Indonesia \\ ${ }^{2}$ Graduate School of Human-Environment Studies, Kyushu University, Fukuoka, Japan \\ ${ }^{3}$ Faculty of Human-Environment Studies, Kyushu University, Fukuoka, Japan \\ Email:soni_nopembri@uny.ac.id,soni.nopembri@gmail.com
}

How to cite this paper: Nopembri, S., Rithaudin, A., Saryono, \& Sugiyama, Y. (2017). Developing Children's Communication and Social Awareness Skills in Volcano Disaster Areas through Physical Education and Sports Programs. Advances in Physical Education, 7, 70-84.

https://doi.org/10.4236/ape.2017.71007

Received: January 28, 2017

Accepted: February 24, 2017

Published: February 27, 2017

Copyright (c) 2017 by authors and Scientific Research Publishing Inc. This work is licensed under the Creative Commons Attribution International License (CC BY 4.0).

http://creativecommons.org/licenses/by/4.0/

(c) (i) Open Access

\begin{abstract}
This study examined the effects of physical education (PE) and sports programs on children's communication and social awareness skills in a volcano disaster-prone area in which a 2010 eruption has already produced trauma. Fourth through sixth grade students $(n=810)$ from fifteen elementary schools in disaster-prone areas, $5-15 \mathrm{~km}$ from the top of the Merapi volcano, were randomly assigned to groups receiving standard and experimental PE and sports programs over 28 weeks in the academic year 2014/2015. Data were collected before and after the program using communication (10 items) and social awareness (10 items) skills scales. Two- and one-way analyses of variance (ANOVA) and paired sample t-tests were used to compare group means at pre- and post-testing. There were significant interaction on communication and social awareness skills scores between the tests and groups, with gains on mean communication and social awareness scores from pretest to post-test and in the intervention group, compared to control groups. The intervention, a psychosocial-based PE and sports program, was an effective way to improve children's communication and social awareness skills.
\end{abstract}

\section{Keywords}

Physical Education, Sports, Communication, Social, Empathy, Skills

\section{Introduction}

The Merapi volcano in Yogyakarta, Indonesia is active and attracts many researchers from around the world (Lavigne et al., 2008). The last and largest 
eruption disaster of Merapi occurred in 2010 and immensely affected both the physical and psychological states of human victims, particularly children. Disasters affect whole societies and have a special negative psychological impact on children (Ronholt, Karsberg, \& Elklit, 2013) who manifest trauma through psychological and behavioral changes that often go unidentified for individual children (Kar, 2009). Survivors who are affected socially, economically, and psychologically may change their behaviors after a disaster (Jogia, Kulatunga, Yates, \& Wedawatta, 2014). Children who have lost their parents in a disaster, are in particular need of long term social and mental health support (Uemoto, Asakawa, Takamiya, Asakawa, \& Inui, 2012).

According to Huitt \& Dawson (2011), a school-wide intervention program can make a subtantial impact on children's social development, provided families and the community also supported it. As a part of the school curriculum, PE and sports can have several benefits on students' psychosocial functioning. PE and sports is the only aspect of the curriculum devoted physical and psychological student (Curelaru, Abalasei, \& Cristea, 2011), and psychological benefits for students are apt to be even more important than skills gained from quality physical activity programs (Wahl-Alexander \& Sinelnikov, 2013), though regular physical activity acts as a resource for personal development and value orientations in relation with health attitudes (Piko \& Keresztes, 2006). However, sports programs can positively contribute in a child's development only under certain conditions (Henley, 2005).

Among the important skills required of students in disaster-prone areas are communication and social awareness. Communication is the process of mutually transferring feelings and thoughts (Aydin, 2015). It is how a person expresses him/herself through interactions with others (Erdogan \& Bayraktar, 2014). Communication is a basic skill learned in the personal and social skills framework (Hollander, Wood, \& Herbert, 2003). Additionally, children who have social awareness will be able to think critically and adapt to social change (Tsui, 2000; Greene \& Kamimura, 2003). Social awareness is the ability to take the perspective of and empathize with others from diverse backgrounds and cultures, to understand social and ethical norms for behavior, and to recognize family, school, and community resources and support (CASEL, 2015). Social awareness is one of the core skills of Social and Emotional Learning (SEL), and it is based on empathy (The Illinois Children's Mental Health Partnership, 2011). The term empathy has been used to refer to two related human abilities: mental perspective taking (cognitive empathy) and the vicarious sharing of emotion (emotional empathy) (Smith, 2006; Cotton, 2001). A cognitive and an affective component of empathy has the highest empirical support (Cavojová, Sirota, \& Belovicová, 2012).

In some opinions, there is a visible relation between physical education and sports, communication skills, and the daily life of students. A physical movement setting is an ideal environment for children to enhance communication skills (Winnick, 2011). Sports may be utilized to support communication and 
self-sustaining development for an entire affected community (Henley, Schweitzer, de Gara, \& Vetter, 2007). A sports environment allows people to learn the skills that help in effective communication, and to use these skills in their social life (Aydin, 2015). Abakay (2013) stated that sports are an important factor in the development of communication skills. In PE, team sports and small group activities can provide several opportunities for children to learn effective communication skills and transfer them into daily life (Hollander, Wood, \& Herbert, 2003).

Many writers have asserted that physical activity and sports can develop social awareness and empathy specifically. Jones, Potrac, Cushion, \& Ronglan (2011) stated that social awareness could change athlete behaviors. Children develop social awareness in movement activities like play (Ismail, 1972), and it is often a goal of physical education teachers to use physical activities to develop children's social awareness (Wiggins-James, James, \& Thompson, 2005). Sports training can improve and increase an empathy ability in and out of school life (Yigiter \& Ustaoglu, 2013), and Sevdalis \& Raab (2014) declared that empathy has a greater potential to be developed through trained human movement. They further noted that empathy in sports and exercise need to be understood for encouraging and enriching the socio-emotional level of sportspersons.

In line with this study, our previous study was found that a psychosocialbased PE and sports program have a significant impact to reduce negative emotional states (depression, anxiety, and stress) of children in the Merapi volcano disaster-prone areas of Indonesia (Nopembri, Saryono, \& Sugiyama, 2016). However, it is particularly important for children in a volcano disaster area to develop psychosocial skills like communication and social awareness that are considered essential to coping with and being prepared for disasters. Therefore, this research set the following goals 1) to investigate the effect of the psychosocial-based PE and sports program on communication and social awareness skills of children in volcano disaster-prone areas in Yogyakarta, Indonesia and 2) to compare the effectiveness of programs with and without new psychosocial emphases with regard to improvement in communication and social awareness skills. We hypothesized that children's communication and social awareness skills will improve through psychosocial-based PE and sports program.

\section{Method}

\subsection{Design}

In the beginning of the study, we developed the psychosocial-based PE and sports program curricula and the scales to measure student communication and social awareness skills. Then, in the experimental stage (shown in Figure 1), participating schools were determined and randomized into three groups: communication and social awareness skills survey scales were administered to all students in before the PE and sports programs; a special theoretical and practically incorporated training about psychosocial-based PE and sports conducted for teachers in the intervention group; a first and second control groups in 


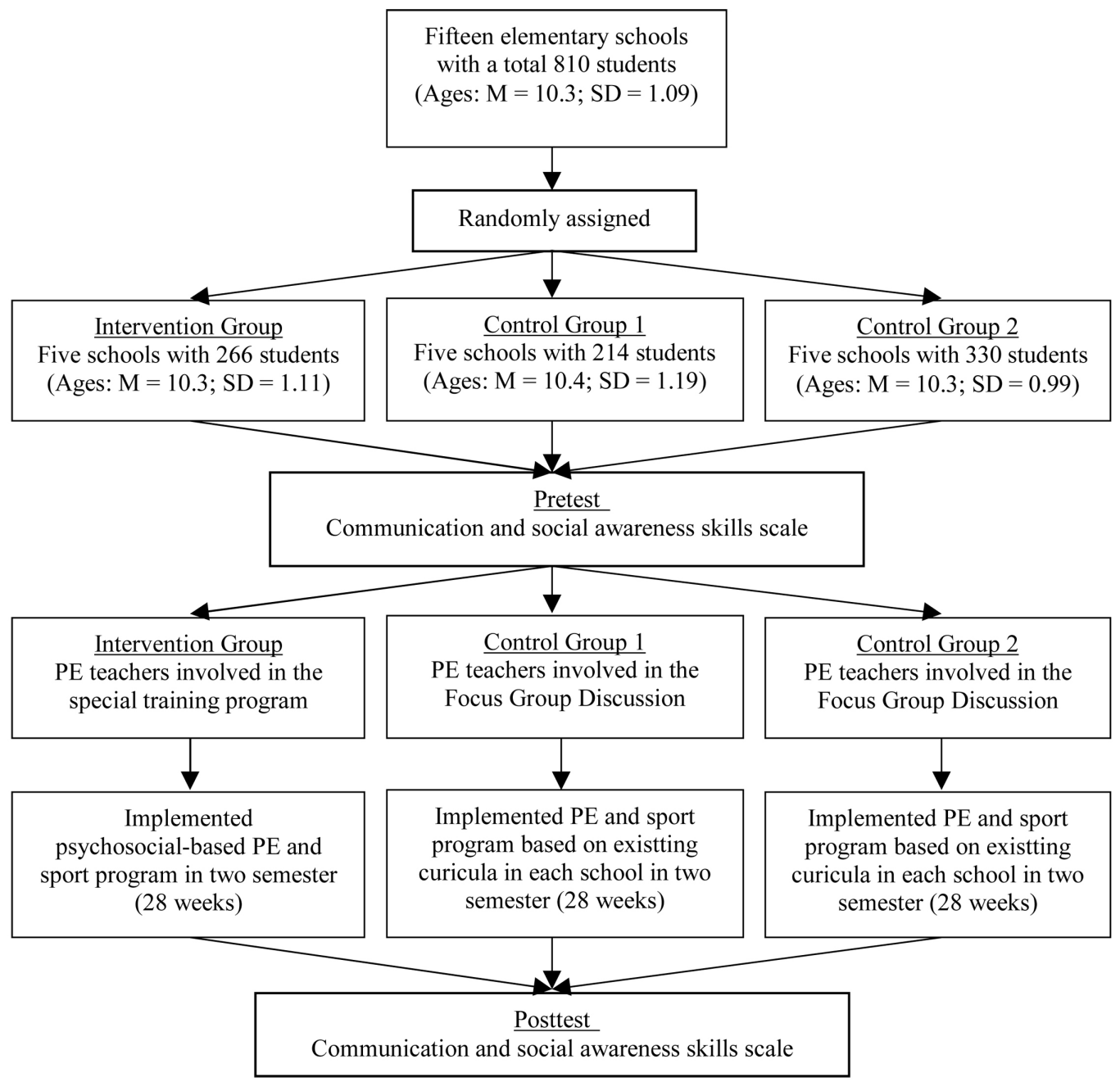

Figure 1. Experimental design of the study.

which teachers were just involved in focused group discussions about their normal programs; all groups were implementing their programs over two semesters during the 2014/15 school year; and at the end of the program, all students measured both skills by the same scales.

The intervention group followed psychosocial-based PE and sports program that employed several forms of physical activity, problem-solving techniques, and coping with stress activities, including relaxation exercises. The intervention program was summarized in handbooks and accompanied with video supplements. The first and second control groups implemented PE and sports programs based on existing curricula in each school. The differences in the PE and sports programs followed by the groups are shown in Table 1 . There are some principle differences between three programs. Firstly, the modification of new curriculum was used in the intervention group but was not modified in the first control group, likewise, the second control group implemented the former curriculum with normal procedures. Secondly, a lesson time in the intervention group performed differently from the first and second control group in the amount of lesson. Third, psychosocial-based physical activity was implemented 
Table 1. Differences in PE and sports program followed by the groups.

\begin{tabular}{|c|c|c|c|}
\hline \multirow{2}{*}{ Aspects } & \multicolumn{3}{|c|}{ Groups } \\
\hline & Intervention & Control 1 & Control 2 \\
\hline Curriculum-based & $\begin{array}{c}2013 \text { Indonesian } \\
\text { Primary School } \\
\text { Curriculum (New). }\end{array}$ & $\begin{array}{l}2013 \text { Indonesian } \\
\text { Primary School } \\
\text { Curriculum (New). }\end{array}$ & $\begin{array}{c}2006 \text { Indonesian } \\
\text { Primary School } \\
\text { Curriculum (former). }\end{array}$ \\
\hline Subject Matters & $\begin{array}{l}\text { Games and sport, } \\
\text { physical fitness, } \\
\text { educational gymnastic, } \\
\text { and rhythmic activity. }\end{array}$ & $\begin{array}{l}\text { Games and sport, } \\
\text { physical fitness, } \\
\text { educational gymnastic, } \\
\text { and rhythmic activity. }\end{array}$ & $\begin{array}{l}\text { Games and sport, } \\
\text { developing the } \\
\text { activity, gymnastic } \\
\text { and rhythmic activity, } \\
\text { water activity } \\
\text { (sometimes), } \\
\text { outdoor education } \\
\text { (sometimes), and } \\
\text { Health (theoretical). }\end{array}$ \\
\hline Lessons times & $\begin{array}{l}\text { Twice a week for each } \\
70 \text { minutes ( } 140 \\
\text { minutes a week) }\end{array}$ & $\begin{array}{l}\text { Once a week for each } \\
140 \text { minutes. }\end{array}$ & $\begin{array}{l}\text { Once a week for } 115 \\
\text { minutes. }\end{array}$ \\
\hline Students & $\begin{array}{l}\text { Students in } 4-6 \\
\text { grades }\end{array}$ & Students all grades. & Students all grades \\
\hline Physical Activities & $\begin{array}{l}43 \text { Physical Activities } \\
\text { based on psychosocial } \\
\text { skills. }\end{array}$ & $\begin{array}{l}\text { Physical Activities are } \\
\text { depending on teachers } \\
\text { and school condition. }\end{array}$ & $\begin{array}{c}\text { Physical Activities are } \\
\text { depending on } \\
\text { teachers and } \\
\text { school condition. }\end{array}$ \\
\hline $\begin{array}{l}\text { Relaxation } \\
\text { exercise }\end{array}$ & $\begin{array}{l}10 \text { minutes Holistic } \\
\text { Relaxation Exercise }\end{array}$ & $\begin{array}{l}\text { Without relaxation } \\
\text { exercise. }\end{array}$ & $\begin{array}{l}\text { Without relaxation } \\
\text { exercise. }\end{array}$ \\
\hline
\end{tabular}

as a part of the intervention program in the intervention group while control groups were performing their each physical activity program. Finally, the 10 minutes relaxation exercise at the end of each lesson was performed in the intervention group to distinguish with control groups.

In this study, we used two control groups with some principle differences in the treatment conditions, which we have been explained above. These differences will clarify the actual influence of the program on the intervention group. Moreover, the two control groups were used to detect latent bias of unobserved variables (Lu \& Rosenbaum, 2004). For example, social/living circumstances could influence psychological factors thus causing differences among the participants. Therefore, researchers' made efforts to reduce the factors that were uncontrollable by using two control groups in the study.

\subsection{Participants}

Fifteen elementary schools in disaster-prone areas, $5-15 \mathrm{~km}$ from the top of the Merapi volcano, were randomly assigned to the intervention and control groups (Ronan \& Johnson, 1999) such that fifteen PE and sports teachers and 810 fourth through sixth-grade students (440 girls and 370 boys) participated in the study, as described in Table 2.

Specifically, with respect to student characteristics (see Table 3), ages ranged from 7 to 15 years $(M=10.3 ; S D=1.09)$. Within the intervention group, there 
Table 2. Teachers and children involved in the study.

\begin{tabular}{ccccccc}
\hline \multirow{3}{*}{ Groups } & School Code & Teachers & \multicolumn{5}{c}{ Students } \\
\cline { 4 - 7 } & & & $4^{\text {th }}$ & $5^{\text {th }}$ & $6^{\text {th }}$ & N \\
\hline \multirow{3}{*}{ Intervention } & IG 1 & E N K & 12 & 15 & 17 & 44 \\
& IG 2 & A D A & 24 & 23 & 15 & 62 \\
& IG 3 & H S & 16 & 17 & 17 & 50 \\
& IG 4 & M & 15 & 9 & 12 & 36 \\
Control 1 & IG 5 & Sn & 31 & 23 & 20 & 74 \\
& CG 1.1 & Sr & 11 & 13 & 19 & 43 \\
& CG 1.2 & S L & 9 & 11 & 11 & 31 \\
& CG 1.3 & Sm & 11 & 6 & 15 & 32 \\
& CG 1.4 & S S & 14 & 14 & 22 & 50 \\
& CG 1.5 & B S & 24 & 19 & 15 & 58 \\
& CG 2.1 & S M & 27 & 20 & 26 & 73 \\
& CG 2.2 & E S & 18 & 22 & 18 & 58 \\
& CG 2.3 & H P & 21 & 31 & 18 & 70 \\
& CG 2.4 & A M K & 16 & 16 & 18 & 50 \\
& CG 2.5 & A W & 33 & 27 & 19 & 79 \\
& & & & & 810 \\
\hline
\end{tabular}

Note: the abbreviation of teachers' name indicated by initial word.

Table 3. Characteristic of children participants.

\begin{tabular}{ccccccccc}
\hline \multirow{2}{*}{ Group } & \multicolumn{2}{c}{ Age } & \multicolumn{3}{c}{ Grade } & \multicolumn{3}{c}{ Sex } \\
\cline { 2 - 8 } & Mean & $\begin{array}{c}\text { Standard } \\
\text { Deviation }\end{array}$ & 4 th & 5 th & 6 th & F & M \\
\hline Intervention & 10.34 & 1.11 & 98 & 87 & 81 & 110 & 156 \\
Control 1 & 10.39 & 1.19 & 69 & 63 & 82 & 105 & 109 \\
Control 2 & 10.29 & 0.99 & 115 & 116 & 99 & 155 & 175 \\
\hline
\end{tabular}

were 266 students consisting of 110 female and 156 male students (ages: $\mathrm{M}=$ 10.3; SD = 1.11). The first control group had 214 students; 105 females and 109 males (ages: $\mathrm{M}=10.4$; $\mathrm{SD}=1.19$ ), and the second control group had 330 students; 155 female and 175 males (ages: $M=10.3$; $S D=0.99$ ). There are not the student with disabilities in this study.

\subsection{Measures}

\subsubsection{Communication Skills}

Authors created the communication skills scale used in pre and post-testing. The scale contained 10 items measuring verbal and nonverbal communication factors. All items were rated by 4-point judgments of how well each item described the child, with values ranging from 0 (not according to me) to 3 (completely according to me). It is to force apathetic respondents to make a choice of the scale 
response categories which are available (Garland, 1991). Verbal communication was measured using four items (e.g., "I saw his eyes while talking to someone"). Total scores ranged from 0 to 12 points. Nonverbal communication was measured using six items (e.g., "I am grateful to those who helped or gave me a gift"). Total scores ranged from 0 to 18 points. Prior to its use in this study, the scale was administered to 745 students. The scale validity was examined by confirmatory factor analysis which each index indicated a good fit: the root mean square error of approximation (RMSEA) was a minimum of 0.051; the GFI index had a fit of 0.973; AGFI index was 0.957, and CFI index was 0.942. A good internal consistency (reliability) of the scale indicated by Cronbach's alpha was 0.699. These verified that the scales were suitable for our sample.

\subsubsection{Social Awareness Skills}

The social awareness skills scale, developed by the authors for this study in simultaneously with the first scale above, contained 10 items measuring children's cognitive and emotional empathy. Cognitive empathy was measured by three items (e.g., "I received a sentence of older people without anger). All items were rated by 4-point frequency scales according to their circumstances, with values ranging from 0 (not according to me) to 3 (completely according to me). Total scores ranged from 0 to 9 points. Emotional empathy was measured using seven items (e.g., "I feel pity for the people affected by the disaster/accident"). Total scores ranged from 0 to 21 points. The validity and reliability were examined from 745 students who filled out the scale. The confirmatory factor analysis which used to indicate the validity shown a model good fit in RMSEA was a minimum of 0.054; GFI index had a fit of 0.973; AGFI index was 0.956, and CFI index was 0.952 . The Cronbach's alpha was 0.794 also indicate good internal consistency (reliability) of this scale.

\subsection{Analysis}

All analyses were performed using SPSS Version 22.0 for Windows, and statistical significance was set at $p<0.05$. The two-way ANOVA with repeated measures used to examine differences between the intervention and control groups before and after the programs. Further analysis to compare the changes across groups used one-way ANOVA. Paired sample t-tests were performed to evaluate differences within groups in both the skills and factors.

\section{Results}

There was a statistically significant interaction of the mean of communication skills scores between the tests and groups $(F(2,807)=5.749, p=0.003)$. In contrast, communication and social awareness scores were not significantly different $(\mathrm{F}(2,807)=0.466, p=0.628)$ when the pre and post-tests groups were combined. The comparison is shown in Figure 2.

The mean change scores for communication skills from pre- to post-intervention were significantly different among the groups. Post hoc analysis of Least 


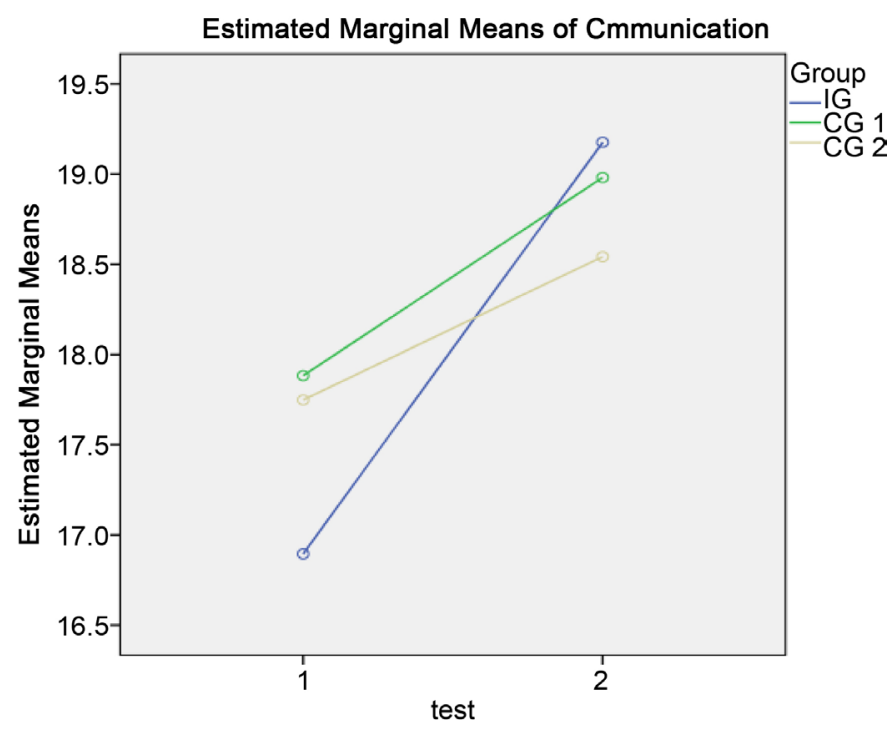

Figure 2. Comparison of the mean of communication skills for three groups.

Significant Difference (LSD) showed statistically significant differences in mean of communication skills scores between intervention and first control group ( $p=$ $0.019)$ and also between intervention and the second group $(p=0.001)$, but not between first and second control groups $(p=0.528)$. There was a statistically significant enhancement in communication skills of the intervention group after the psychosocial-based PE and sports program $(\mathrm{t}(265)=-6.691 ; p=0.000)$. Similarly, the first control group $(\mathrm{t}(213)=-3.226 ; p=0.001)$ also showed a statistically significant increase in communication skills scores after their program. This was also found in the second control group $(t(329)=-2.513 ; p=0.012)$ that showed a statistically significant increase in communication skills scores. Thus, it can be concluded that all groups showed an increase in communication skills as a result of their respective programs. The enhancement of communication skills in all groups is summarized in Table 4.

As shown in Table 5, our statistical analysis also showed a significant enhancement of verbal $(\mathrm{t}(265)=-8.305 ; p=0.000)$ and non-verbal $(\mathrm{t}(265)=$ -2.638; $p=0.009$ ) skills in the intervention group. However, the first control group showed a significant increase in verbal skills $(\mathrm{t}(213)=-5.568 ; p=0.000)$, but not in non-verbal skills $(\mathrm{t}(213)=-0.113 ; p=0.910)$. Also, the second control group showed a significant increase in verbal skills $(\mathrm{t}(329)=-2.996 ; p=0.003)$, but not in non-verbal skills $(\mathrm{t}(329)=-0.995 ; p=0.321)$.

There was a significant interaction of the mean of social awareness scores between test and groups $(\mathrm{F}(2,807)=10.838, p=0.000)$. However, there were no significant differences $(\mathrm{F}(2,807)=0.639, p=0.528)$ when the pre and post-tests groups were combined. Figure 3 illustrates the comparison among the three groups with regard to social awareness skills. The social awareness skills difference scores from pre-test to post-test were also significantly different across groups, and post hoc analysis of Least Significant Difference (LSD) showed significant differences of mean social awareness skills between intervention and 
Table 4. Paired-sample t-tests for communication skills.

\begin{tabular}{ccccccc}
\hline \multirow{2}{*}{ Group } & \multicolumn{2}{c}{ Mean } & \multicolumn{2}{c}{ Standard Deviation } & \multirow{2}{*}{$\mathrm{t}$} & Sig. \\
\cline { 2 - 5 } & Pre & Post & Pre & Post & & \\
\hline Intervention & 16.89 & 19.18 & 5.448 & 5.754 & -6.691 & $0.000^{\star}$ \\
Control 1 & 17.88 & 18.89 & 4.355 & 5.494 & -3.226 & $0.001^{\star}$ \\
Control 2 & 17.75 & 18.54 & 5.068 & 5.634 & -2.513 & $0.012^{\star}$ \\
\hline
\end{tabular}

${ }^{*} p<0.05$ in two tailed test.

Table 5. Paired-sample t-tests for verbal and non-verbal skills.

\begin{tabular}{lccccccc}
\hline \multirow{2}{*}{ Group } & \multirow{2}{*}{ Factors } & \multicolumn{3}{c}{ Mean } & \multicolumn{5}{c}{ Standard Deviation } & \multirow{2}{*}{$\mathrm{t}$} & Sig. \\
\cline { 3 - 6 } & & Pre & Post & Pre & Post & & \\
\hline \multirow{2}{*}{ Intervention } & Verbal & 4.78 & 6.46 & 2.605 & 2.762 & -8.305 & $0.000^{*}$ \\
& Non-verbal & 12.12 & 12.72 & 4.061 & 3.846 & -2.638 & $0.009^{*}$ \\
\multirow{2}{*}{ Control 1 } & Verbal & 5.06 & 6.12 & 2.353 & 2.479 & -5.568 & $0.000^{*}$ \\
& Non-verbal & 12.83 & 12.86 & 3.502 & 4.049 & -0.113 & 0.910 \\
\multirow{2}{*}{ Control 2 } & Verbal & 5.15 & 5.71 & 2.722 & 2.870 & -2.996 & $0.003^{*}$ \\
& Non-verbal & 12.60 & 12.83 & 3.549 & 3.739 & -0.995 & 0.321 \\
\hline
\end{tabular}

${ }^{\star} p<0.05$ in two tailed test.

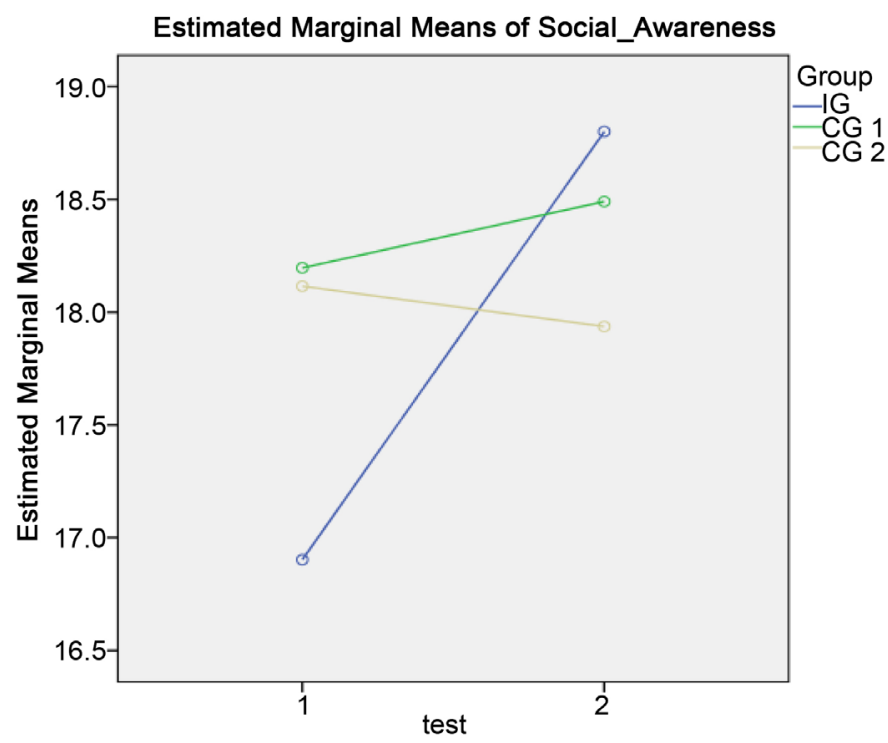

Figure 3. Comparison of mean of social awareness skills for three groups.

first control groups $(p=0.002)$ and also between intervention and second control groups $(p=0.000)$ but not between the two control groups $(p=0.332)$. There was a significant increase in social awareness skills after the psychosocial-based PE and sports program for the intervention group $(\mathrm{t}(265)=-5.803$; $p=0.000)$. On the other hand, the first $(\mathrm{t}(213)=-0.782 ; p=0.435)$ and second $(\mathrm{t}(329)=0.565 ; p=0.572)$ control groups did not show a significant increase. In brief, the intervention group showed improvement in social awareness skills as a 
result of the implemented program. See Table 6.

As shown in Table 7, there was a significant enhancement, both in emotional $(\mathrm{t}(265)=-2.437 ; p=0.015)$ and cognitive $(\mathrm{t}(265)=-8.764 ; p=0.000)$ empathy skills for the intervention group. The first control group showed significant increase in cognitive empathy $(\mathrm{t}(213)=-2.499 ; p=0.013)$ but not for emotional empathy $(\mathrm{t}(213)=0.655 ; p=0.513)$ skills. On the other hand, the second control group did not show any significant increase, both in emotional $(\mathrm{t}(329)=1.565$; $p=0.118)$ and cognitive $(\mathrm{t}(329)=-1.441 ; p=0.151)$ empathy skills after the program.

\section{Discussion}

Our research results indicated that all three PE and sports programs we studied were associated with a significant improvement in communication skills, including the special program in the intervention group. This supports our hypothesis that psychosocial-based PE and sports program improve communication skills of children in volcano disaster areas. Our findings also confirmed the purpose of the present study, that is, the findings were in line with our initial expectations. Our present study results were also in synch with those of several similar studies. For example, Aydin (2015) found that university students who participated in PE and sports in school displayed higher level of communication skills. Aykora, Tekin, Ozdag, Dereceli, \& Uzunkaya (2010) also found that the PE students had higher communication skills than fine arts students. Another finding showed that the communication skills of high school students who were actively involved in sports activities were higher than students with a sedentary lifestyle

Table 6. Paired-sample t-tests for social awareness skills.

\begin{tabular}{ccccccc}
\hline \multirow{2}{*}{ Group } & \multicolumn{2}{c}{ Mean } & \multicolumn{2}{c}{ Standard Deviation } & \multirow{2}{*}{$\mathrm{t}$} & Sig. \\
\cline { 2 - 5 } & Pre & Post & Pre & Post & & \\
\hline Intervention & 16.90 & 18.80 & 5.325 & 5.931 & -5.803 & $0.000^{*}$ \\
Control 1 & 18.19 & 18.49 & 4.974 & 5.876 & -0.782 & 0.435 \\
Control 2 & 18.12 & 17.94 & 5.815 & 5.815 & 0.565 & 0.572 \\
\hline
\end{tabular}

${ }^{*} p<0.05$ in two tailed test.

Table 7. Paired-sample t-tests for cognitive and emotional empathy skills.

\begin{tabular}{|c|c|c|c|c|c|c|c|}
\hline \multirow[t]{2}{*}{ Group } & \multirow[t]{2}{*}{ Factors } & \multicolumn{2}{|c|}{ Mean } & \multicolumn{2}{|c|}{$\begin{array}{l}\text { Standard } \\
\text { Deviation }\end{array}$} & \multirow[t]{2}{*}{$\mathrm{t}$} & \multirow[t]{2}{*}{ Sig. } \\
\hline & & Pre & Post & Pre & Post & & \\
\hline \multirow{2}{*}{ Intervention } & Cognitive & 3.42 & 4.70 & 1.916 & 2.068 & -8.764 & $0.000^{*}$ \\
\hline & Emotional & 13.48 & 14.10 & 4.319 & 4.479 & -2.437 & $0.015^{*}$ \\
\hline \multirow{2}{*}{ Control 1} & Cognitive & 4.05 & 4.47 & 1.820 & 2.041 & -2.499 & $0.013^{*}$ \\
\hline & Emotional & 14.15 & 13.95 & 3.971 & 4.584 & 0.655 & 0.513 \\
\hline \multirow{2}{*}{ Control 2} & Cognitive & 3.02 & 4.03 & 1.887 & 2.204 & -1.441 & 0.151 \\
\hline & Emotional & 14.29 & 13.90 & 3.975 & 4.347 & 1.565 & 0.118 \\
\hline
\end{tabular}

${ }^{*} p<0.05$ in two tailed test. 
(Abakay, 2013). He also impressed that sport plays a very important role in enhancing communication skills and decreasing submissive behaviors (Abakay, 2013). Erdogan \& Bayraktar (2014) studies found that participating in sports led to an increase in communication skills.

In this study, communication skills comprised two factors, namely, verbal and nonverbal communication. Our results indicate that children in all groups of the program had significant improvement in verbal communication skills. In line with that, Preja (2013) stated that in physical education and sports activity, the students constantly use verbal as well as non-verbal communication, like codes, signs, drawings, etc. Whereas in nonverbal communication skills, a significant improvement just was found in the intervention group. It's supported by studies which found that nonverbal skills significantly improved when students actively participated in sports activities (Sugiyama, 2012; Sugiyama et al., 2009). Likewise, the finding that sports and play activities can assist youth to non-verbally access, express, and resolve a myriad of troubling issues (Henley, 2005).

An overall analysis revealed psychosocial-based PE and sports program had a significant effect on the improvement of children's social awareness skills in the intervention group. In contrast, another program in the two control groups did not have a significant effect on social awareness skills. These key findings confirm that the hypothesis of the study was supported. In line with the study of physical education and sports classes, Akelaitis (2015) found that the older students had a higher level of social awareness ability than younger ones. Further supporting this statement, Velardo, Elliott, Filiault, \& Drummond (2010) stated that a big challenge faced by the society with regard to youth sports participation benefits is improving social awareness.

In the study, social awareness consisted of two factors, namely, cognitive and emotional empathy. It is according to The Illinois Children's Mental Health Partnership (2011) that empathy is the foundation of social awareness. Some opinions explained that empathy is the ability that involves the cognitive and affective aspects of the human being (Blair, 2005; Garton \& Gringart, 2005; Zhou \& Ee, 2012). Our results showed that a significant improvement of both emotional and cognitive empathy of the children just was found in the intervention group. These results support the findings of some previous studies, for example, García-López \& Gutiérrez (2013) found that sports education intervention program could improve student's empathy. Another study stated that the sports program had an important effect on empathy ability of the vocational school students (Yigiter \& Ustaoglu, 2013). Similarly, sport-based life skills positively impacted the adolescent's level of empathic concern (Brunelle, Danish, \& Forneris, 2007). Akelaitis (2015) also found that physical education classes resulted in higher level empathy ability of younger students.

As described earlier, researchers have sought to minimize the uncontrolled factors using two control groups. However, it is possible that these factors were the limitations of the study. The differences in the teaching abilities of teachers in the intervention group were reduced by special training about the programs 
to be implemented. Researchers and principals were involved in intensive discussions about the program before implementation to ensure agreement with the school policies regarding curriculum in PE and sports. To maximize the implementation of the intervention group program, researchers procured various $\mathrm{PE}$ and sports equipment, which was necessary to meet the deficiencies of school infrastructure.

\section{Conclusion}

The psychosocial-based PE and sports program lead to an increase in both communication and social awareness skills of children in volcano disaster-prone areas. The program also had a positive effect on the factors of investigative skills. Comparing with another PE and sports program, a properly planned, executed, and measured psychosocial-based $\mathrm{PE}$ and sports intervention programs would be an effective way to improve both communication and social skills of children in the volcano disaster-prone area. On the other hand, there may be some weaknesses in this study such as differences in the teaching abilities of teachers, differences in school policies regarding curriculum in PE and sports, and school infrastructure deficiencies. Further research examining the implications of this intervention program on the improvement of other psychosocial skills and relationship with physical condition of children is needed. In further studies, the effectiveness of the program should be carried out under conditions of other disaster areas such as floods, earthquakes, or war.

\section{Acknowledgements}

We have to express the highest appreciation to the principals, PE teachers, and students who were participated in the study. The authors also would like to thanks to KAKENHI Grant Number JP24500704 and DITLITABMAS KEMRISTEKDIKTI for supporting our research. Especially, the first author is thankful to the DG-RSTHE scholarship to provide a study abroad opportunity.

\section{References}

Abakay, U. (2013). Investigation of the Effect of Sport on Submissive Behavior and Communication of High School Students. Global Journal of Medical, Physical and Health Education, 1, 44-49.

Akelaitis, A. V. (2015). Social Skills Expression of Senior High School Age Students in Physical Education Classes. European Journal of Contemporary Education, 14, 232238.

Aydin, A. D. (2015). Assessment of Communication Skills of Physical Education and Sport Students in Turkish Universities. Universal Journal of Educational Research, 3, 943-948. https://doi.org/10.13189/ujer.2015.031125

Aykora, E., Tekin, A., Ozdag, S., Dereceli, C., \& Uzunkaya, D. (2010). Communication Skills and Emphatic Tendency: Physical Education and Fine Arts Students. Journal Ovidius University Annals, Physical Education and Sport/Science, Movement and Health Series, 10, 639-643.

Blair, R. J. (2005). Responding to the Emotions of Others: Dissociating Forms of Empathy 
through the Study of Typical and Psychiatric Populations. Consciousness and Cognition, 14, 698-718. https://doi.org/10.1016/j.concog.2005.06.004

Brunelle, J., Danish, S. J., \& Forneris, T. (2007). The Impact of a Sport-Based Life Skill Program on Adolescent Prosocial Values. Applied Development Science, 11, 43-55. https://doi.org/10.1080/10888690709336722

Cavojová, V., Sirota, M., \& Belovicová (2012). Slovak Validation of the Basic Empathy Scale in Pre-Adolescents. Studia Psychologica, 54, 195-208.

Collaborative for Academic, Social, Emotional Learning (CASEL) (2015) Social and Emotional Learning Core Competencies. Chicago, IL: Author. http://www.casel.org/social-and-emotional-learning/core-competencies

Cotton, K. (2001). Developing Empathy in Children and Youth. School Improvement Research Series Close Up \# 13. http://www.nwre1.org/scpd/sirs/7/cu13.html

Curelaru, M., Abalasei, B., \& Cristea, M. (2011). Psychosocial Correlates of the Need for Physical Education and Sports in High School. Journal of Social Sciences, 7, 521-528. https://doi.org/10.3844/jssp.2011.521.528

Erdogan, T., \& Bayraktar, G. (2014). Effects of Sports on Communication Skills: A Research on Teacher Candidates. Research on Humanities and Social Sciences, 4, 68-74.

García-López, L. M., \& Gutierrez, D. (2013). The Effects of a Sport Education Season on Empathy and Assertiveness. Physical Education and Sport Pedagogy, 20, 1-16.

Garland, R. (1991). The Mid-Point on a Rating Scale: Is It Desirable? Marketing Bulletin, 2, 66-70.

Garton, A. F., \& Gringart, E. (2005). The Development of a Scale to Measure Empathy in 8- and 9-Year Old Children. Australian Journal of Education and Development Psychology, 5, 17-25.

Greene, S. R., \& Kamimura, M. (2003). Ties That Bind: Enhanced Social Awareness Development through Interactions with Diverse Peers. In The Annual Meeting of the Association for Study of Higher Education Portland (pp. 213-228). Portland, Oregon: Association for Study of Higher Education.

Henley, R. (2005). Helping Children Overcome Disaster Trauma through Post Emergency Psychosocial Sports Program. Biel: Swiss Academy for Development.

Henley, R., Schweizer, I. C., De Gara, F., \& Vetter, S. (2007). How Psychosocial Sport \& Play Programs Help Youth Manage Adversity: A Review of What We Know \& What We Should Research. International Journal of Psychosocial Rehabilitation, 12, 51-58.

Hollander, D. B., Wood, R. J., \& Herbert, E. P. (2003). Protecting Students against Substance Abuse Behaviors: Integrating Personal and Social Skills into Physical Education. Journal of Physical Education, Recreation, \& Dance, 74, 45-48.

https://doi.org/10.1080/07303084.2003.10608485

Huitt, W. \& Dawson, C. (2011). Social Development: Why It Is Important and How to Impact It. In Educational Psychology Interactive. Valdosta, GA: Valdosta State University. http://www.edpsycinteractive.org/papers/socdev.pdf

Ismail, A. H. (1972). Integrated Development. In J. E. Kane (Ed.), Psychological Aspect of Physical Education and Sport (pp. 1-37). New York, NY: Routledge.

Jogia, J., Kulatunga, U., Yates, G. P., \& Wedawatta, G. (2014). Culture and the Psychological Impacts of Natural Disasters: Implications for Disaster Management and Disaster Mental Health. The Built \& Human Environment Review, 7, 1-10.

Jones, R. L., Potrac, P., Cushion, C., \& Ronglan, L. T. (2011). The Sociology of Sports Coaching. New York, NY: Routledge.

Kar, N. (2009). Psychological Impact of Disaster on Children: Review of Assessment and 
Interventions. World Journal of Pediatric, 5, 5-11.

https://doi.org/10.1007/s12519-009-0001-x

Lavigne, F., De Coster, B., Juvin, N., Flohic, F., Gaillard, J.-C., Texier, P. et al. (2008). People's Behavior in the Face of Volcanic Hazards: Perspectives' from Javanese Communities, Indonesia. Journal of Volcanology and Geothermal Research, 172, 273-287. https://doi.org/10.1016/j.jvolgeores.2007.12.013

Lu, B., \& Rosenbaum, P. R. (2004). Optimal Pairing Matching with Two Control Groups. Journal of Computational and Graphical Statistic, 13, 422-434. https://doi.org/10.1198/1061860043470

Nopembri, S., Saryono, \& Sugiyama, Y. (2016). Reducing Children's Negative Emotional States through Physical Education and Sport in Disaster-Prone Areas. Advances in Physical Education, 6, 10-18. https://doi.org/10.4236/ape.2016.61002

Piko, B. F., \& Kereztes, N. (2006). Physical Activity, Psychosocial Health and Life Goals among Youth. Journal of Community Health, 31, 136-145. https://doi.org/10.1007/s10900-005-9004-2

Preja, C. A. (2013). Verbal and Non-Verbal Communication in Sport Culture. Palestrica of the Third Millennium-Civilization and Sport, 14, 239-243.

Ronan, K. R., \& Johnston, D. M. (1999). Behaviorally-Based Interventions for Children Following Volcanic Eruptions: An Evaluation of Effectiveness. Disaster Prevention and Management, 8, 169-176. https://doi.org/10.1108/09653569910275364

Ronholt, S., Karsberg, S., \& Elklit, A. (2013). Preliminary Evidence for a Classroom Based Psychosocial Intervention for Disaster Exposed Children with Posttraumatic Stress Symptomatology. Child Youth Care Forum, 42, 617-631. https://doi.org/10.1007/s10566-013-9220-3

Sevdalis, V., \& Raab, M. (2014). Empathy in Sports, Exercise, and the Performing Arts. Psychology of Sport and Exercise, 15, 173-179. https://doi.org/10.1016/j.psychsport.2013.10.013

Smith, A. (2006). Cognitive Empathy and Emotional Empathy in Human Behavior and Evolution. The Psychological Record, 56, 3-12.

Sugiyama, Y. (2012). Process of Acquisition, Improvement, and Development of Nonverbal Skills through Physical Education (Grant Number 21500564). Research Report, JSPS KAKENHI.

Sugiyama, Y., Nagao, Y., Yamasaki, M., Kawazu. K., Wang, X., \& Kumasaki, E. (2009). The Relationship between Social Orientation and the Improvement of Communication Skills through Sports Education Classes. In The 12th ISSP World Congress of Sport Psychology (p. 277). Marrakech: International Society of Sport Psychology.

The Illinois Children's Mental Health Partnership (2011). Social Awareness. Social Emotional Links, $1,1$.

Tsui, L. (2000). Effects of Campus Culture on Students' Critical Thinking. The Review of Higher Education, 23, 421-441. https://doi.org/10.1353/rhe.2000.0020

Uemoto, M., Asakawa, A., Takamiya, S., Asakawa, K., \& Inui, A. (2012). Kobe Earthquake and Post-Traumatic Stress in School-Aged Children. International Journal of Behavior and Medicine, 19, 243-251. https://doi.org/10.1007/s12529-011-9184-3

Velardo, S., Elliott, S., Filiault, S. M., \& Drummond, M. J. N. (2010). The Role of Health Literacy in Parents' Decision Making in Children's Sporting Participation. Journal of Student Wellbeing, 4, 55-65. https://doi.org/10.21913/JSW.v4i2.725

Wahl-Alexander, Z., \& Sinelnikov, O. A. (2013). Using Physical Activity for Emotional 
Recovery after a Natural Disaster. Journal of Physical Education, Recreation \& Dance, 84, 23. https://doi.org/10.1080/07303084.2013.767729

Wiggins-James, N., James, R., \& Thompson, G. (2005). AS PE for AQA. Oxford: Hart Court Education Ltd.

Winnick, J. P. (2011). Adapted Physical Education and Sport. Champaign, IL: Human Kinetics.

Yigiter, K., \& Ustaoglu, P. (2013). Effect of the Sport Training on Empathy Ability of the Vocational School Students in Turkey. Journal of Education and Practice, 4, 210-213.

Zhou, M., \& Ee, J. (2012). Development of the Social Emotional Competence Questionnaire (SECQ). The International Journal of Emotional Education, 4, 27-42.

Submit or recommend next manuscript to SCIRP and we will provide best service for you:

Accepting pre-submission inquiries through Email, Facebook, LinkedIn, Twitter, etc. A wide selection of journals (inclusive of 9 subjects, more than 200 journals)

Providing 24-hour high-quality service

User-friendly online submission system

Fair and swift peer-review system

Efficient typesetting and proofreading procedure

Display of the result of downloads and visits, as well as the number of cited articles

Maximum dissemination of your research work

Submit your manuscript at: http://papersubmission.scirp.org/

Or contact ape@scirp.org 